\title{
The Emergence of Different Local Resilience Arrangements Regarding Extreme Weather Events in Small Municipalities-A Case Study from the Wielkopolska Region, Poland
}

\author{
Adam Choryński 1,2,*(D), Iwona Pińskwar 1,3 ${ }^{1}$, Dariusz Graczyk ${ }^{1,3}$ and Michał Krzyżaniak 4 (D)
}

1 Institute for Agricultural and Forest Environment, Polish Academy of Sciences, Bukowska 19, 60-809 Poznan, Poland; iwona.pinskwar@isrl.poznan.pl (I.P.); darekgraczyk@wp.pl (D.G.)

2 Meteorology Laboratory, Department of Construction and Geoengineering, Faculty of Environmental Engineering and Mechanical Engineering, Poznan University of Life Sciences, Piatkowska 94, 60-649 Poznań, Poland

3 Department of Land Improvement, Environmental Development and Spatial Management, Faculty of Environmental Engineering and Mechanical Engineering, Poznan University of Life Sciences, Piątkowska 94E, 60-649 Poznan, Poland

4 Department of Landscape Architecture, Faculty of Agriculture, Horticulture and Bioengineering, Poznan University of Life Sciences, Dabrowskiego 159, 60-594 Poznan, Poland; michal.krzyzaniak@up.poznan.pl

* Correspondence: adam.chorynski@gmail.com

\section{check for} updates

Citation: Choryński, A.; Pińskwar, I.; Graczyk, D.; Krzyżaniak, M. The Emergence of Different Local Resilience Arrangements Regarding Extreme Weather Events in Small Municipalities-A Case Study from the Wielkopolska Region, Poland. Sustainability 2022, 14, 2052. https:// doi.org/10.3390/su14042052

Academic Editors: Baojie He, Ayyoob Sharifi and Chi Feng

Received: 30 December 2021

Accepted: 8 February 2022

Published: 11 February 2022

Publisher's Note: MDPI stays neutral with regard to jurisdictional claims in published maps and institutional affiliations.

Copyright: (c) 2022 by the authors. Licensee MDPI, Basel, Switzerland. This article is an open access article distributed under the terms and conditions of the Creative Commons Attribution (CC BY) license (https:/ / creativecommons.org/licenses/by/ $4.0 /)$.

\begin{abstract}
Compared with other parts of the world, Poland is a relatively safe country in terms of natural disasters. Nevertheless, extreme weather events have become a significant threat in recent years, especially for local communities. These are exposed to intense rainfall, heavy wind, and heatwaves, as are larger towns. However, small municipalities have different economic, social, and human potential for undertaking preventive actions regarding meteorological extremes. In this paper, we are looking at what activities local communities from the Wielkopolska region in Poland undertake to cope with extreme weather events - specifically, heavy rainfall and heatwaves. We analyze the municipalities that are most and least exposed to extremes, based on meteorological data. These are further compared with local resilience measures in the event of extreme meteorological events through the risk management analysis of selected municipalities. The emergence of two approaches regarding extreme weather events has been observed. First, local arrangements consist of different resilience types. Both of the identified approaches are concentrated around rescue activities, representing recovery resilience. They differ in the second component of resilience: municipalities that have suffered more from weather extremes manifest more resistance resilience, whereas those communities where fewer meteorological events took place demonstrate more creativity-type resilience.
\end{abstract}

Keywords: extreme weather events; resilience; adaptation; municipalities; heat waves; extreme rainfall; Poland

\section{Introduction}

As a result of many changes taking place globally-increasing urbanization, climate change, economic growth, and the corresponding increase in people's disposable incomeextreme weather events pose an increasingly severe threat to lives and habitats. They are difficult to predict, and they may be even more dangerous in the future. The concentration of resources and inhabitants in a small space means that people and material goods are ever more exposed to the destructive effects of intense meteorological phenomena. The impact of urbanization processes on this increased vulnerability to losses also results from changes in spatial structure. For example, sidewalks, streets, squares, and parking lots are covered with impermeable layers of concrete or asphalt. As a result, the rain cannot naturally drain away into the ground, resulting in urban floods from heavy rainfall. Local authorities try to counteract this by installing expensive rainwater drainage systems, but it is often 
insufficient to prevent damage in the face of extreme rain. Moreover, many studies indicate that as a consequence of further climate change, extreme weather events will become more common and increase in intensity [1].

Local communities may adopt various ways of dealing with threats, manifested by a certain resilience. Therefore, this study aims to analyze the kinds of specific activities that are followed in local municipalities that are more exposed to extreme weather events, as well as those where events occurred less, to establish different responses to the risks associated with extreme weather events.

\subsection{Local Communities Exposure and Extreme Weather Events}

In this study, weather events are interpreted in terms of defining natural disasters as processes that affect social routines [2]. These, in turn, constitute repetitive, recognizable patterns of behavior and independent actions carried out by various actors [3]. Therefore, extreme weather events are an element that disrupts the typical functioning of the local community systems, made up of individuals, institutions, and natural conditions. Consequently, they require specific actions to avoid disruption or restore system efficiency to the pre-event status quo.

The term "extreme" can mean both the maximum and minimum values of a climatic event observed at a specific time [4]. Extreme weather events are also defined by the criteria used: (1) frequency of occurrence, (2) intensity, (3) scale of material losses [5].

Local communities are exposed to disruptions in functioning due to the consequences of extreme weather events. There is an interaction between natural and social systems, whereby heavy rainfall or strong winds become a disruptive element that local systems have to deal with. As a result, the residents of both large and small towns may suffer. However, this very threat to human health, and sometimes also to human life, although extremely important, is not the only aspect elevating extreme meteorological events to the rank of a severe problem. It is also the issue of potential financial losses resulting from damage to individuals, enterprises, and common property. Small towns have a completely different potential for preparations, actions during an event, and reactions after a disruption than large cities. Large towns are more financially affluent in terms of financial, material, and human resources. However, smaller communities still have to cope with the same meteorological hazards as large ones.

Moreover, rural and urban-rural municipalities are less frequently studied than large metropolitan areas [2]. Therefore, we have focused on small municipalities (rural and urban-rural). Due to the availability of meteorological data for the area, we analyzed municipalities from the Wielkopolska region in Poland.

An increase in the frequency and intensity of extreme weather events [6] is assumed for research purposes, and a corresponding increase in financial losses and the number of people directly threatened by natural disasters is described [7]. Climate warming enhances the potential for intense precipitation: more water vapor can be stored in warmer air. According to the Clausius-Clapeyron law, this sensitivity is $6-7 \% \mathrm{~K}^{-1}$. Poland's analysis of the 99th percentile of precipitation for the two periods of 1989-2018 and 1959-1988 indicate an increase in sensitivity $\left(6.06 \% /{ }^{\circ} \mathrm{C}\right.$ and $5.26 \% /{ }^{\circ} \mathrm{C}$, respectively). The potential for more extreme precipitation is growing [8].

Nevertheless, heavy rainfall and strong winds are not the only extreme weather events that local communities must deal with. Around the world, not only in Poland, people are faced with droughts [9] and increasingly dangerous heatwaves. High temperatures, which remain high for many days, are the cause of an increased number of deaths. In Poland, an increase in mortality due to heatwaves is also evidenced, mainly in people suffering from cardiovascular diseases and the elderly [10]. In Poland, in 2016, as much as $64.5 \%$ of all firefighting interventions were against local threats, including those resulting from extreme weather events [11].

Extreme weather events management is subject to the scale of an event and relates to the actions of authorities at the state, region, county, and municipality levels [12]. As these 
extreme events are often occurring locally, affecting local communities, Poland's lowest level of local government administration is the one that must deal with the problem. Poland's crisis management system was introduced in 2007, supported by an Act regarding crisis management [13]. According to the terms of this document, notifications and warnings regarding imminent threats are the responsibility of the Institute of Meteorology and Water Management-National Research Institute (IMGW-PIB). Crisis management planning and operational activities mainly fall to the rescue and firefighting units of the State Fire Service [14]. On the one hand, crisis management departments play a leading role in Poland at particular levels of the country's administration-region (voivodeship), poviat, and municipality - as bodies responsible for coordination activities. They are headed by a representative of the authorities for a given level, i.e., the head of the region, the county, and the mayor [15].

On the other hand, when it comes to operational issues, most competencies lie with the State Fire Service [16]. The structure of Polish crisis management in terms of public administration consists of four levels relating to its administration. At the local level, this is based on the self-government administration of the municipality and includes: (a) the mayor; (b) the municipal crisis management team (appointed in a crisis situation); (c) the municipal crisis management center. Crisis management centers are institutions responsible for coordinating the activities of the various rescue units involved, inter alia, in helping the victims of the consequences of extreme weather events. One of the main tasks of these centers is collecting and enabling the effective flow of information, as well as undertaking joint operations between various services: rescue and firefighting units of the State Fire Service, units of the Volunteer Fire Department, police, and municipal guards. At the lowest level of public administration, there is no obligation to establish crisis management centers, but most communities have such units. In cases where there are insufficient resources to deal with local threats or to respond to the scale of an event, assistance is provided by the counterpart of crisis management centers at the higher administration level (county or region). Then, the county head represents the government and coordinates the activities.

\subsection{Extreme Weather Events Resilience}

Resilience can be understood as the overall ability of the system to deal with disruptions; it can be used to analyze the various municipalities' adaptation activities concerning the threat presented by extreme weather events and their consequences at the municipal level. Local systems deal with problems by returning to the status quo before the event as soon as possible. Therefore, a municipality's ability to regain functionality, maintain its most essential functions (i.e., the ability to prevent the complete disintegration of a given system), and develop features that enable more effective prevention and coping with the problem is called resilience [17].

The concept of resilience is used in many research perspectives relating to socioecological systems. These are, among others, social learning, social networks, and adaptability [17]. A socio-ecologically resilient system is one where disruption (a natural hazard in the analyzed case) can create new solutions for innovation and development. Social resilience is also sometimes referred to as the ability to "bounce back" [18].

Kimhi and Shomai [19] distinguished three basic approaches to resilience, identifying three types of resilience: (a) resistance, (b) recovery, and (c) creativity.

Resistance can be understood as the established system's resistance to event-induced transformation, for example, the endurance of the social structure [20]. On the other hand, the ability to recover is the ability to go through a catastrophe $[19,20]$ and return ("bounce back") to the level it was at before the event [21]. Moreover, according to Aguirre, a more resilient society will recover faster [22]. Maguire and Hagan [23] also identify the element of creativity, by which it is possible to adapt to new conditions through learning from experience. Moreover, the category of resilience includes two seemingly contradictory elements [24]: (1) stability — the ability to resist a given system; (2) variability-the ability 
of the system to adapt. This distinction, as applied in this paper, is further explored in Section 2.3.2.

The problem of resilience is often raised in research on the consequences of climate change [25-27]. Chelleri [28], Zhang, and Li [29] mention creating or building resilience, especially in urban areas. Local systems, therefore, demonstrate a different constellation of resilience types, in which one specific form dominates the others, or where the type of system is more balanced. Resilience, as defined in this way, reflects the nature of the event response activities undertaken in a municipality.

Problems related to natural disasters may act as shocks to particular systems. In this sense, extreme weather events, also considered natural disasters, are an element that should be examined through the lens of the resilience concept [30]. This analysis looks at urban space and assesses the four abilities of resilience: (a) the ability to absorb; (b) the ability to adapt to change; (c) the ability to transform; (d) the ability to learn from past events. This study focuses on three types of resilience, to which these abilities belong: (a) resistance (ability to absorb); (b) recovery (ability to adapt to change and ability to transform); (c) creativity (ability to learn from past events) [31].

Adaptation to climate-related extreme weather events has also been analyzed, focusing on communities [32]. It has been said that the stakeholders' involvement, including local stakeholders, is crucial for implementing practices targeted at reducing or transferring climate risks.

In this research centered on Poland, we are faced with a limited number of previous studies relating to resilience in the context of the consequences of climate change, such as extreme weather events, particularly when considering small towns and not large cities. The analyzed elements in this study, taking into account the concept of resilience, are issues concerning the adaptation and functioning of local systems in the event of a flood hazard [12,33]. The authors developed a tool to assess the implementation of adaptation solutions in the communities of the Nysa Kłodzka Sub-Basin. Flood risk and flood risk governance arrangements are frequently examined in Poland, using the resilience concept (e.g., [34-37]). Masik and Gajewski [38] focused on the urban resilience of Polish cities in response to climate change. They analyzed the urban adaptation plans of Polish cities where the population exceeds 100,000. The study found that the programs focus on activities that are characteristic of resistance and recovery resilience, within three subsections of the resilience concept (absorptive coping capacity, adaptive capacity, and transformative capacity). A lack of new tools for social participation is observed as part of resilience arrangements. Referring to the approach proposed in this study, we can note that there are no elements characteristic of creativity resilience. Research on resilience in Poland has also included issues arising from other areas, such as economics [39]. An overview of some of the research conducted on resilience in the face of extreme weather events or other natural disasters has been presented in Table 1 .

This study is probably the first attempt to look at the problem of coping with the meteorological threats in Poland from the point of view of local communities in small towns, through the prism of the resilience concept. The value of this study is the linking of meteorological data, identifying extreme cases in terms of weather hazards, with social data explaining how local risk management systems that are related to weather extremes operate. The proposed approach can be applied successfully in other regions, enabling the characterization of local management systems and, subsequently, an analysis of the solutions used and their effectiveness through an extension of the research. 
Table 1. Overview of different research papers dealing with resilience against extreme weather events or natural disasters from various perspectives in Poland and other countries.

\begin{tabular}{|c|c|c|}
\hline & $\begin{array}{l}\text { Similar to Proposed Resilience } \\
\text { Concepts }\end{array}$ & $\begin{array}{c}\text { Different Approaches of Resilience Concepts in Extreme Weather } \\
\text { Events Research }\end{array}$ \\
\hline \multirow[t]{3}{*}{ Poland } & $\begin{array}{l}\text { Matczak et al. [40]_analysis of } \\
\text { flood risk } \\
\text { resilience in Poland, using the } \\
\text { policy } \\
\text { arrangements approach } \\
\text { framework }\end{array}$ & $\begin{array}{c}\text { Dumieński et al. [12]—analysis of adaptation solutions in Polish } \\
\text { communities to flood risk }\end{array}$ \\
\hline & & $\begin{array}{c}\text { Masik and Gajewski [38] — analysis of urban resilience regarding } \\
\text { climate change, with a focus on large towns }\end{array}$ \\
\hline & & $\begin{array}{l}\text { Listwan-Franczak et al. [41] —analysis of the natural disaster insurance } \\
\text { system as a part of disaster risk reduction in Poland }\end{array}$ \\
\hline \multirow{8}{*}{ Other locations } & $\begin{array}{l}\text { Driessen et al. [35]—the paper } \\
\text { covers flood } \\
\text { resilience in Europe, based } \\
\text { on policy } \\
\text { arrangements approach analysis }\end{array}$ & $\begin{array}{l}\text { Lucini [42] - analysis of the resilience of local communities that face } \\
\text { earthquakes, with a focus on crisis and rescue operations, as well as } \\
\text { communication and risk perception }\end{array}$ \\
\hline & & $\begin{array}{l}\text { Jacobs et al. [43]-analysis of resilience to climate extremes of natural } \\
\text { resources, through the phases of emergency management cycles }\end{array}$ \\
\hline & & $\begin{array}{l}\text { Rapaport et al. [44]—analysis of different communities, including rural, } \\
\text { which are seen as a strong predictor of community resilience }\end{array}$ \\
\hline & & $\begin{array}{l}\text { Carpenter et al. [45]-propose an extreme events resilience approach } \\
\text { concentrated on the recovery-resilience of socio-ecological systems }\end{array}$ \\
\hline & & $\begin{array}{l}\text { Cutter et al. [46] - comparison of resilience in urban and rural areas, } \\
\text { where different capitals are behind in terms of disaster resilience }\end{array}$ \\
\hline & & $\begin{array}{l}\text { Lai et al. [47] — provide an overview of priorities to enhance } \\
\text { community resilience in rural areas in Taiwan }\end{array}$ \\
\hline & & $\begin{array}{c}\text { Linnenluecke and Griffiths [48] —assessment of organizational } \\
\text { resilience to weather extremes_including two dimensions of resilience: } \\
\text { impact resistance and rapidity }\end{array}$ \\
\hline & & Ahern [49]—presents strategies to build urban resilience capacity \\
\hline
\end{tabular}

\section{Materials and Methods}

\subsection{Research Design}

This study concerns various municipalities' responses and methods of functioning in 2010-2016. Its purpose is to define the relationship between extreme weather events and the formation of specific local resilience arrangements. The selected period makes it possible to include not only periods of intense meteorological phenomena but also calmer years in the research. Therefore, the main research question is to indicate to what extent the experiencing of (in the sense of exposure to) extreme weather events affects the adoption of specific forms of action in municipalities, including changes within the framework of the resilience concept. The test also indicates specific values regarding the number of weather extremes necessitating selected actions under local resilience arrangements. In light of flood risk research and the related measures [24], it could be hypothesized that greater exposure to extreme weather events would necessitate local arrangements dominated by resistancetype resilience. Our analyses of Polish flood risk governance arrangements suggest that the more exposed to natural disasters a local community is, the more probable it is that a resistance-resilience-type arrangement would emerge in Polish scenarios [16,24,40] (this response differs in other countries [50]). Nevertheless, as we prove later in the paper, this is 
not the case when dealing with extreme weather events in small municipalities. Here, the dominant observed type of response is recovery-resilience.

Although resilience to extreme weather events has been analyzed by several authors [25], we found none stating a similar hypothesis. Nevertheless, some research suggests that a selected type of resilience should be adopted to prepare for future events [51]. In addition, some analyses show local communities' reactions to natural disasters [42]. However, these analyses do not focus on the extent to which extreme weather events result in the emergence of a specific resilience arrangement.

We have undertaken two-track actions, concerning meteorological and social data, to verify our hypothesis and answer the research questions. The first selection was limited to 8 municipalities for which weather data of the highest quality is available, making it possible to process these data further. Among Wielkopolska municipalities (226), rural areas (115), and urban-rural areas (92), municipalities were selected due to the topic of interest of the authors, excluding urban municipalities (19). Then, from among these municipalities, towns were selected where the official meteorological stations of the Institute of Meteorology and Water Management-National Research Institute (IMGW-PIB) are located. There are 87 rain measuring stations in the Wielkopolskie Voivodeship [52], monitored by the State Hydrological and Meteorological Service (PSHM) of the Institute of Meteorology and Water Management-National Research Institute. Unfortunately, only a few stations measure air temperature in the studied area. We have analyzed the meteorological data available for these stations. We have also conducted in-depth interviews with key local actors representing institutions that manage extreme weather events in the municipalities.

Furthermore, we have decided to focus on four out of the eight initially analyzed micro-case studies [53]. This second selection is based on the severity of the extreme weather events that the municipalities have experienced. Therefore, we have chosen to look specifically at the two most affected by weather extremes in the region (Krzyż Wielkopolski and Kórnik) and the two that suffered the least from heavy rainfall and heatwaves in the period of 2010-2016 (Szamotuły and Nowy Tomyśl).

The qualitative data obtained through in-depth interviews allowed us to build up an image of local extreme weather events management. The interviews were transcribed and further analyzed with the qualitative data analysis software NVivo $10[54,55]$. The local actors' answers were coded [56,57] within the dimensions of the policy arrangements approach and in terms of resilience types. The coded answers were counted within every dimension to determine which resilience type was mainly represented, giving an image of resilience type saturation. Further, local resilience arrangements were determined by averaging the saturation results representing the observed resilience types in particular dimensions in the analyzed municipalities. A similar research design has already been successfully employed [58]. We have discovered that four researched municipalities stand out as the most pronounced in terms of present local resilience arrangements. The meteorological analyses were further cross-referenced with data on local resilience arrangements.

\subsection{Analyzed Municipalities}

In this paper, four municipalities are analyzed. These are Krzyż Wielkopolski, Kórnik, Nowy Tomyśl, and Szamotuły. Figure 1 depicts a map of Poland with the indicated examined municipalities in the Wielkopolska region (a) and the land-cover type of the selected municipalities (b). 


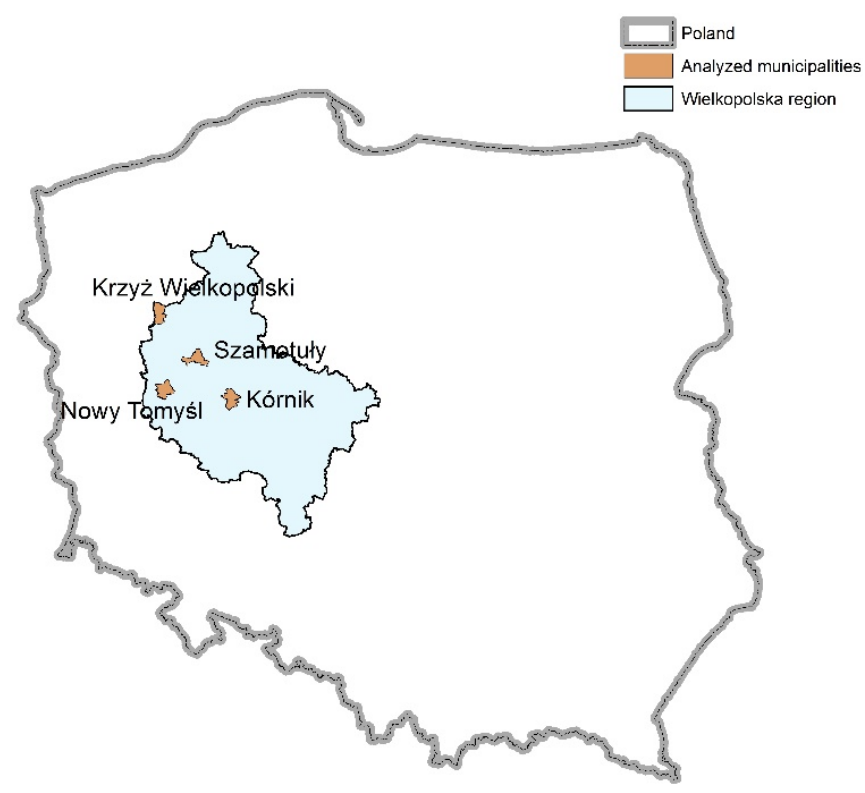

(a)
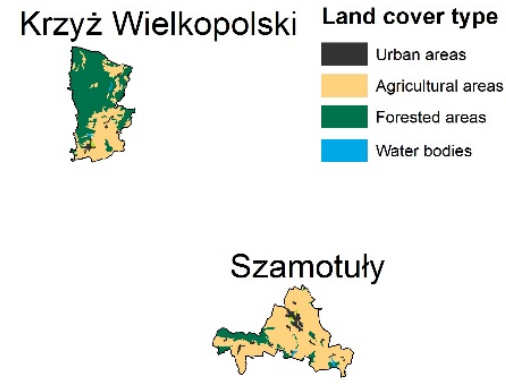

Nowy Tomyśl

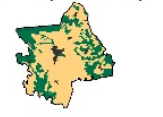

(b)

Figure 1. Analyzed municipalities: (a) map of Poland indicating studied municipalities in the Wielkopolska region; (b) land-cover type of selected municipalities, based on data from Corine Land Cover 2012 (CLC 2012).

Important information on the land type of the researched municipalities and general demographic data are included in Table 2.

Table 2. Land data (CLC 2012) and demographic data [59] of the studied municipalities.

\begin{tabular}{ccccc}
\hline & Kórnik & Krzyż Wlkp. & Nowy Tomyśl & Szamotuły \\
\hline Area $\left(\mathrm{km}^{2}\right)$ & 186.0 & 174.2 & 186.4 & 175.4 \\
Urban areas $(\%)$ & 7.1 & 2.1 & 3.4 & 5.9 \\
Agricultural areas (\%) & 62.2 & 36.9 & 63.7 & 79.5 \\
Forested areas (\%) & 28.4 & 60.5 & 32.9 & 13.8 \\
Water bodies (\%) & 2.1 & 0.5 & 0.0 & 0.8 \\
\hline Number of inhabitants & 29,901 & 8754 & 26,624 & 29,931 \\
Pop. density (per km $\left.{ }^{2}\right)$ & 144.63 & 50.3 & 143.14 & 170.05 \\
\hline
\end{tabular}

The settlement network of the Wielkopolska region consists of 109 cities and 5500 villages. A characteristic feature of the area is the large number of small towns, which account for nearly half of all cities (50), and a relatively large number of medium-sized cities (36). The urbanization rate is $56.4 \%$ and is lower than the average for Poland. The average population density is 114 people $/ \mathrm{km}^{2}$ [59].

The municipality of Krzyż Wielkopolski is part of the county of Czarnków-Trzcianka, with more than half of its area being covered by forests. A low level of development characterizes the rural-urban municipality of Krzyż Wielkopolski. It is distinguished by low social and human capital, poor technical infrastructure, little housing development, and depopulation [60].

The municipality of Kórnik is located in the Wielkopolska region, in the southern part of Poznań County. It is an urban-rural municipality, including 26 villages. According to Poniży [61], almost half of the municipality's area is covered by environmental protection plans. In 2004-2009, there was an increase in built-up areas (over 110\%) and surface water (over $2 \%$ ) in the municipality. Conversely, the areas of forests (approx. $0.4 \%$ ), arable land (over 6\%), and meadows and pastures (over 2\%) decreased [61]. From 2008 to 2014, the number of people who lived in the studied municipality increased by over $26 \%$. Thus, 
Kórnik is one of the municipalities characterized by the region's highest dynamics of population growth. The priorities of the municipality's authorities include protection of the environment and cultural heritage and development of tourism [62].

The spatial layout of the Nowy Tomyśl municipality consists of the central unit-the town of Nowy Tomyśl and the remaining 18 precincts-in the form of village councils. The population density is 2836 people $/ \mathrm{km}^{2}$, which distinguishes the town from its surroundings, while for the entire municipality, this indicator increased annually from 2015 to 2019 , from 140 people $/ \mathrm{km}^{2}$ to almost 145 people $/ \mathrm{km}^{2}$ in 2019. Compact, downtown, multi-family housing is predominant in Nowy Tomyśl. Conversely, single-family and farm buildings dominate in rural areas. The municipalities' development strategy is based on tradition and respect for the natural environment, which should be characterized by a management system adapted to climate change. This can be achieved by increasing the acreage of green areas by developing the degraded parts of the municipality and introducing tree planting [63].

The town and municipality of Szamotuly are located in the county of Szamotuly, in the Wielkopolska region. The Szamotuły municipality includes the town of Szamotuły as well as 25 villages. There are no large-scale natural habitats, such as national and landscape parks, reserves, or protected landscape areas [64]. Unfortunately, among the strategic goals of the municipality (from 2014), there are no identifiable measures for environmental protection or reducing the consequences of natural disasters [65].

\subsection{Analytical Framework for Resilience Analysis}

\subsubsection{Policy Arrangements Approach}

We used the policy arrangements approach (PAA) $[66,67]$ to test the resilience of the selected municipalities. This analytical framework is used to research public policies [67]. Still, as the authors of the concept themselves mention, it can be applied to various research areas. This analytical framework assumes looking at the problem under study from the perspective of four dimensions: (a) actors (active individuals, institutions, enterprises, the present day); (b) resources (material, financial, human, knowledge, power); (c) norms (laws, informal norms); (d) discourses (the ways of expression and definition that are used by actors). Such an analysis makes it possible to recognize the types of resilience in municipalities. The shaping of a policy system and its structuring is understood as the institutionalization process of a given policy system and its constant change at the same time. The main advantage of this approach is its potential to analyze and understand the continuous processes of policy systems institutionalization. This process results from the interaction between the actors involved in implementing policies in everyday activities and the strategies of social and political change. Therefore, it is a relationship between areas of activity and the institutional space. The authors of the discussed analytical framework define institutionalization as a phenomenon in which specific patterns and the patterns of people's actions are created. Consequently, behavior transforms into permanent constructions that begin to structure behavior [66]. Therefore, stability and change are key features of those research areas that use a policy arrangements approach.

In research dealing with resilience arrangements in terms of the adaptational plans of large Polish cities, a method with some similarities to the policy arrangements approach has been proposed [38]. Instead of the PAA dimensions, the study's authors used environmental, social, and economic dimensions of resilience. These, to some extent, correspond to the dimensions of PAA. The policy arrangement approach has been widely utilized to analyze water and flood risk management in several European countries [68-73]. This methodology has also been applied when analyzing Polish flood risk management arrangements [71,74].

\subsubsection{Resilience Types}

A distinction between the three types of resilience [19] has been applied for the purposes of this paper. These are (a) resistance, (b) recovery, and (c) creativity; their characteristics are presented below, as well as being collated in Table 3. 
Table 3. Characteristics of applied resilience types.

\begin{tabular}{cc}
\hline Resilience Type & Characteristic \\
\hline Resistance & $\begin{array}{c}\text { Focus on the stability of the system } \\
\text { Ability to resist an event unchanged }\end{array}$ \\
Special attention to infrastructural measures (i.e., rainwater systems) \\
Recovery \\
Reaching stability of the system through internal dynamics \\
Ability to absorb shocks and to return to the status quo \\
before an event
\end{tabular}

\section{- Resistance}

In the case of a local system characterized by a resilience that comprises a type of resistance, the most critical element is the system's stability and durability. It is also about the constant maintenance of its development [75]. Such a system can resist and survive in the face of a disrupting factor [76]. The activities are of an engineering nature, where thinking is focused on controlling natural hazards [24]. In this case, the system does not change its structure under the influence of disturbance, and there are also no internal changes. It can withstand uncertainty, complexity, and change at different levels and scales, under the conditions of a human-dominated space [75]. De Graaf et al. [77] also indicate that resilience means increasing the system's threshold above which threats, including extreme weather events, could cause harm. Due to the lack of dynamics and variability, this resilience type of response is sometimes referred to by some researchers as resistance, rather than resilience, which is in opposition to it. Nevertheless, in the literature on resilience, resistance is usually considered one of its aspects [31].

\section{- Recovery}

A distinguishing element of local system resilience in terms of the type of recovery is the ability of the system to absorb shock events [75] and return to the status quo before the event [31]. The local system has the specific ability to survive unchanged. Ongoing internal changes relating to certain aspects of the procedure and the modification of certain activities allow the system's structure to remain intact while maintaining all essential functions [24]. The literature also noted that small-scale transformations result in resilience over an extended period [78]. With this type of resilience, the system cannot block the impact of shocks, unlike resistance. Instead, it can absorb the effects of an event, react to it, and regain efficiency. This is a more ecological approach, where less invasive and less interfering environmental activities, rather than classic building solutions, are considered to deal with factors disrupting the system's normal functioning [24]. Some researchers point to the resilience component, an expression of engineering thinking about resilience, which refers to the reaction after the event- "bounce-back" - an element characteristic of resistance-type resilience [24]. This study assumes that "bounce-back" is an expression of internal dynamics, characteristic of the resilience seen in this type of recovery [79-81].

\section{- Creativity}

Resilience in the form of creativity emphasizes the variability of a system [24]. The critical elements of this type of resilience are adaptive and transformational abilities [82]. A creative-type resilient system can sustain itself through constant learning and collaboration, enabling it to respond to changing circumstances [83]. Pahl-Wostl et al. [84] also indicate that such a system involves various activities and strategies. The system's capacity to transform and adapt is also expressed in the ability to use an opportunity to modify the way it functions, which is the moment of disrupting the system's functioning. In such 
a system, the learning process results from participation and discussion [84] and more decentralized forms of decision-making [85].

\subsection{In-Depth Interviews}

Data for the analysis were collected through in-depth interviews with representatives of the local risk management arrangements (40 in-depth interviews, with five in each of the eight surveyed municipalities). It was assumed that the respondents would have the most significant knowledge of dealing with extreme weather events in a given municipality and the people most involved in this process, representing various institutions active in managing the risk inherent in extreme meteorological events. Apart from representatives from the municipal crisis management departments and rescue services representatives, such as the fire brigade and municipal police, it was necessary to include people representing other organizations involved in local systems for a complete picture of the cases under study. The roles of the interviewed actors within the studied municipalities are presented in Appendix A.

The in-depth interviews were conducted as semi-structured interviews [56]. Questions were divided into sections, according to the four dimensions of the policy arrangements approach. The interviews were recorded when the interviewees agreed to it (most cases). The duration of the interviews varied between $40 \mathrm{~min}$ and $90 \mathrm{~min}$, while most of them took about $60 \mathrm{~min}$. In-depth interviews were conducted between December 2017 and the end of February 2018. Each actor was interviewed once, and five interviews were undertaken per municipality.

Furthermore, the interviews have been transcribed. The interviewees' statements were coded, taking into account the dimensions of the analysis (policy arrangement approach dimensions) using NVivo 10 qualitative data software. The viewpoints, assigned as characteristic of a specific resilience type, were collected and counted to provide an image of the local resilience arrangement in terms of a particular dimension of the policy arrangements approach. A compilation of the results in different dimensions represents the local resilience arrangement.

The questions stated in the interviews, and an overview of the obtained answers within different dimensions of the policy arrangements approach and representing a specified resilience type, are presented in Appendix B.

\subsection{Meteorological Data}

In this paper, we used data from meteorological stations located in the area of the analyzed municipalities: Szamotuły, Kórnik, Krzyż Wielkopolski, and the station of Paproć situated near Nowy Tomyśl (see Figure 1). Data covering the interval from 1981 to 2016 were provided by the Institute of Meteorology and Water Management-State Research Institute (IMGW-PIB) [86]. Extreme meteorological events were calculated for 2010-2016 and were then compared to 1981-2010. Daily climatological data (precipitation and maximum temperature) for the whole period were available for Kórnik.For three other stations until the end of 2014. Daily precipitation data were available for these three stations, and for maximum temperature, daily data for 2015-2016 were calculated based on sub-hourly data. Additionally, for the Paproć reference period, there was a gap in data from the beginning of November 1985 to the end of April 1986, which did not impact heatwave data but may slightly influence extreme precipitation results during the reference period. In addition, the daily maximum temperature for the period of 2015-2016 may be slightly underestimated because the given values are for 10-minute intervals, not from the maximum thermometer.

Extreme meteorological events per year in this paper are considered to be:

- The number of days with precipitation equal to or over $10 \mathrm{~mm}(\mathrm{R} 10 \mathrm{~mm})$ as the number of extreme precipitation events;

- The maximum daily precipitation (RX1day) as the magnitude of extreme precipitation events; 
- The sum of rainfall exceeding $10 \mathrm{~mm}$ (example: $3 \mathrm{~mm}$ shows precipitation of $13 \mathrm{~mm}$; PRCPTOT10mm) is also the magnitude of extreme precipitation events;

- The number of days with a maximum temperature that is equal to or above $30{ }^{\circ} \mathrm{C}$ (Tmax30) as the number of extreme heatwave events;

- The maximum temperature (Tmax) as the magnitude.

Furthermore, we analyzed two extreme events-the number of days with precipitation equal to or over $10 \mathrm{~mm}(\mathrm{R} 10 \mathrm{~mm})$ and days with a maximum temperature equal to or above $30{ }^{\circ} \mathrm{C}$ (Tmax30) for 42 synoptic stations for Poland during 2010-2016- to illustrate the problem using the chosen extremes, against the background of the whole country.

\section{Results}

\subsection{Extreme Meteorological Events}

Figure 2 depicts the mean annual values for Poland for two extreme events. During the analyzed period of 2010-2016, Poland faced severe floods in 2010 [8] and two very extreme heatwaves in 2010 and 2015 [9,10]. The total precipitation and abundant rainfall for Wielkopolska were lower than in the south of the country, where mountainous regions dominate. However, central Poland is located in the belt of lowlands, with a slight terrain slope. Therefore, these areas are more vulnerable to flooding and local floods. Furthermore, the 2015 heatwave was very severe in the southern part of Poland. Therefore, for a more extended period than 2010-2016, Wielkopolska would also be in the area most exposed to heatwaves $[9,10]$.

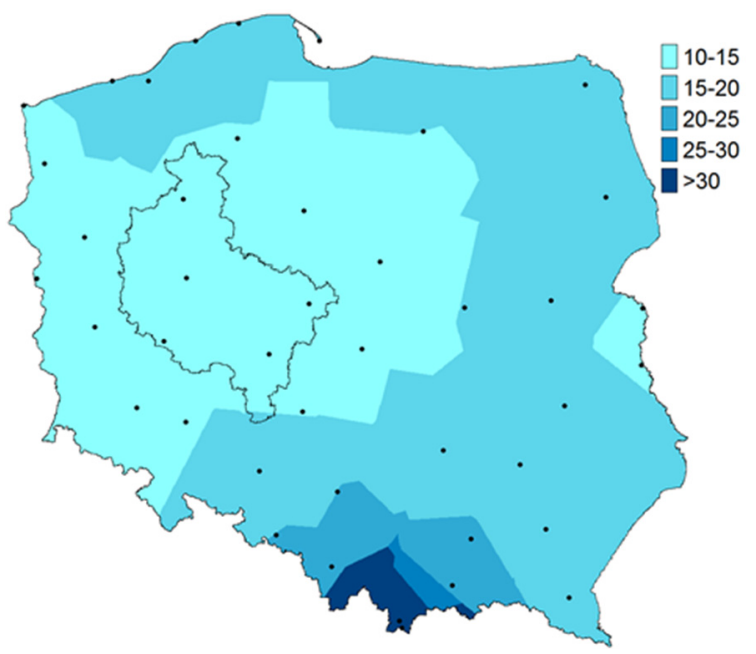

(a)

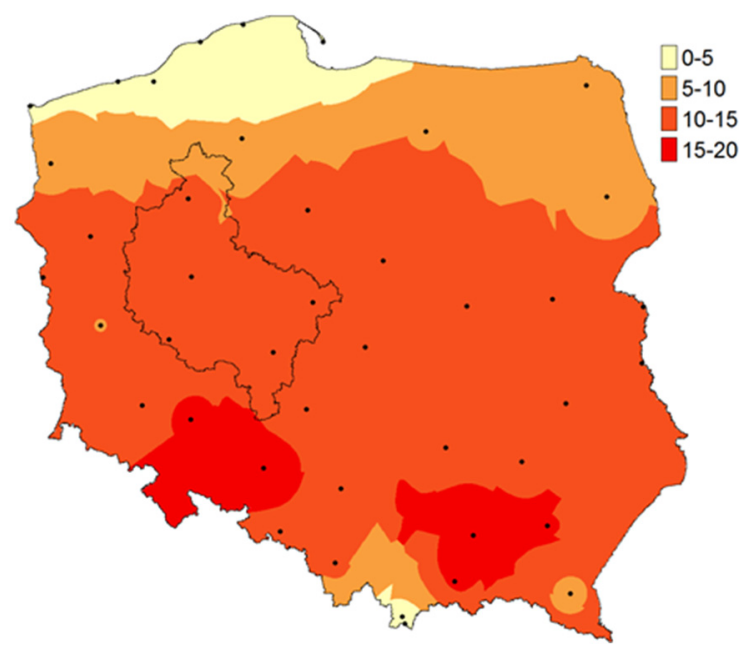

(b)

Figure 2. The annual mean number of days during the analysis period of 2010-2016, based on data from 42 synoptic stations in Poland with extreme weather conditions: (a) precipitation equal to or over $10 \mathrm{~mm}(\mathrm{R} 10 \mathrm{~mm})$; (b) maximum temperature equal to or above $30^{\circ} \mathrm{C}$ (Tmax30).

Analysis of the extreme meteorological events in four small municipalities revealed that those in the period of 2010-2016 for all stations were more extreme than in 1981-2010. Although in many cases, the most extreme events occurred during the period of 2010-2016, the mean values for this interval were much higher than mean values from the reference period (Tables 4 and 5). The number of days with precipitation equal to or over $10 \mathrm{~mm}$ ranged from 2 to $25 \%$; the maximum daily precipitation was also higher by 24 to $43 \%$, and total precipitation from extreme precipitation was higher by 20 to $43 \%$. 
Table 4. Extreme precipitation events in the studied municipalities. The increases in mean values for the analyzed period in 2010-2016, compared to the mean value from the reference period 1981-2010, are given in brackets. The highest values are in bold.

\begin{tabular}{|c|c|c|c|c|c|}
\hline Index & Year & Kórnik & Krzyż Wlkp. & Nowy Tomyśl (Paproć) & Szamotuły \\
\hline \multirow{11}{*}{$\begin{array}{l}\text { Number of days with } \\
\text { precipitation equal to or } \\
\text { above } 10 \mathrm{~mm} \text { (R10mm) } \\
\text { (days) }\end{array}$} & 1981-2010: Max (Year) & $22(1994,2010)$ & $21(2010)$ & $18(1981,1997,2002,2010)$ & $18(1993)$ \\
\hline & Min (Year) & $6(1982,1989)$ & $7(1982,1983,1990)$ & $5(1982,1985,1992)$ & 2 (1992) \\
\hline & Mean & 12.8 & 12.5 & 11.8 & 10.8 \\
\hline & 2010 & 22 & 21 & 18 & 17 \\
\hline & 2011 & 9 & 14 & 12 & 10 \\
\hline & 2012 & 15 & 21 & 13 & 15 \\
\hline & 2013 & 11 & 10 & 9 & 11 \\
\hline & 2014 & 9 & 16 & 13 & 7 \\
\hline & 2015 & 8 & 10 & 8 & 6 \\
\hline & 2016 & 18 & 17 & 11 & 12 \\
\hline & Mean & $13.4(5 \%)$ & $15.6(25 \%)$ & $12.0(2 \%)$ & $11.1(3 \%)$ \\
\hline \multirow{11}{*}{$\begin{array}{l}\text { Maximum daily } \\
\text { precipitation (RX1day) } \\
(\mathrm{mm})\end{array}$} & 1981-2010: Max (Year) & $65.4(1996)$ & $61.2(1996)$ & $79.1(1996)$ & $71.4(1996)$ \\
\hline & Min (Year) & $13.7(1982)$ & $17.0(2004)$ & $12.1(2004)$ & $17.2(1982)$ \\
\hline & Mean & 33.4 & 32.8 & 38.9 & 33.6 \\
\hline & 2010 & 40.2 & 37.0 & 73.0 & 52.9 \\
\hline & 2011 & 35.5 & 68.2 & 30.9 & 57.0 \\
\hline & 2012 & 40.5 & 67.0 & 33.4 & 35.6 \\
\hline & 2013 & 44.8 & 47.0 & 124.0 & 60.0 \\
\hline & 2014 & 40.3 & 32.1 & 28.0 & 38.5 \\
\hline & 2015 & 23.7 & 18.2 & 25.1 & 26.5 \\
\hline & 2016 & 64.3 & 58.0 & 61.9 & 66.3 \\
\hline & Mean & $41.3(24 \%)$ & $46.8(43 \%)$ & $53.8(38 \%)$ & $48.1(43 \%)$ \\
\hline \multirow{11}{*}{$\begin{array}{c}\text { Sum of rainfall } \\
\text { exceeding } \\
10 \mathrm{~mm} \\
\text { (PRCPTOT10mm) } \\
(\mathrm{mm})\end{array}$} & 1981-2010: Max (Year) & $159.9(2010)$ & 136.9 (1996) & $185.4(1981)$ & $161.0(1996)$ \\
\hline & Min (Year) & $9.7(1982)$ & $29.2(1985)$ & $9.6(2004)$ & $13.4(1982)$ \\
\hline & Mean & 83.1 & 81.7 & 90.0 & 77.1 \\
\hline & 2010 & 159.9 & 111.7 & 145.9 & 159.4 \\
\hline & 2011 & 77.8 & 114.3 & 71.6 & 90.1 \\
\hline & 2012 & 95.3 & 198.3 & 97.9 & 84.3 \\
\hline & 2013 & 147.2 & 133.6 & 218.1 & 84.2 \\
\hline & 2014 & 73.0 & 81.3 & 53.7 & 61.4 \\
\hline & 2015 & 41.7 & 42.0 & 48.5 & 31.8 \\
\hline & 2016 & 196.3 & 134.7 & 121.5 & 144.0 \\
\hline & Mean & $113.0(36 \%)$ & $116.6(43 \%)$ & $108.2(20 \%)$ & $93.6(21 \%)$ \\
\hline
\end{tabular}

Table 5. Extreme heatwave events in the researched municipalities. The increases for mean values for the analyzed period of 2010-2016, compared to the mean value from the reference period of 1981-2010, are given in brackets. The highest values are in bold.

\begin{tabular}{|c|c|c|c|c|c|}
\hline Index & Year & Kórnik & Krzyż Wlkp. & Nowy Tomyśl (Paproć) & Szamotuły \\
\hline \multirow{11}{*}{$\begin{array}{l}\text { Number of days with a } \\
\text { maximum temperature } \\
\text { equal to or above } 30^{\circ} \mathrm{C} \\
\text { (Tmax30) } \\
\text { (days) }\end{array}$} & 1981-2010: Max (Year) & $26(2006)$ & $24(2006)$ & $23(2006)$ & 27 (2006) \\
\hline & Min (Year) & $2(1981)$ & 1 (1993) & $1(1981,1993)$ & 0 (1981) \\
\hline & Mean & 9.1 & 8.9 & 8.4 & 7.5 \\
\hline & 2010 & 17 & 23 & 21 & 16 \\
\hline & 2011 & 6 & 7 & 5 & 5 \\
\hline & 2012 & 15 & 13 & 11 & 9 \\
\hline & 2013 & 10 & 10 & 11 & 10 \\
\hline & 2014 & 19 & 20 & 16 & 18 \\
\hline & 2015 & 27 & 24 & 23 & 20 \\
\hline & 2016 & 16 & 11 & 8 & 6 \\
\hline & Mean & 15.7 (72\%; 6.6 days) & 15.4 (73\%; 6,5 days) & 13.6 (62\%; 5.2 days) & $12.0(60 \% ; 4.5$ days $)$ \\
\hline \multirow{11}{*}{$\begin{array}{c}\text { Maximum temperature } \\
(\text { Tmax }) \\
\left({ }^{\circ} \mathrm{C}\right)\end{array}$} & 1981-2010: Max (Year) & $38.0(1994)$ & $38.0(1998)$ & $37.6(1994)$ & $37.5(1992)$ \\
\hline & Min (Year) & $30.5(1981)$ & $30.8(1981)$ & $30.6(1981)$ & $29.5(1981)$ \\
\hline & Mean & 34.2 & 34.3 & 34.0 & 33.8 \\
\hline & 2010 & 35.8 & 36.9 & 36.4 & 36.2 \\
\hline & 2011 & 30.8 & 32.1 & 30.9 & 31.8 \\
\hline & 2012 & 34.6 & 33.3 & 35.3 & 34.6 \\
\hline & 2013 & 34.4 & 34.4 & 34.2 & 33.2 \\
\hline & 2014 & 34.8 & 35.3 & 34.2 & 34.6 \\
\hline & 2015 & 37.8 & 38.3 & 37.4 & 36.4 \\
\hline & 2016 & 34.8 & 34.5 & 34.2 & 32.7 \\
\hline & Mean & $34.7\left(0.5^{\circ} \mathrm{C}\right)$ & $35.0\left(0.7^{\circ} \mathrm{C}\right)$ & $34.7\left(0.7^{\circ} \mathrm{C}\right)$ & $34.2\left(0.4^{\circ} \mathrm{C}\right)$ \\
\hline
\end{tabular}

In addition, during the intervals in 2010-2016 of the analyzing stations, heatwaves were more severe than in the reference period. As a result, the mean number of hot days was higher by 60 to $73 \%$, and the mean maximum temperature was higher by 0.4 to $0.7^{\circ} \mathrm{C}$. 


\subsection{Local Resilience Arrangements}

Based on the research carried out on local resilience arrangements in the case of extreme weather events adaptation, it can be concluded that two distinct approaches have emerged. First, each of the local systems is dominated by rescue efforts. These mainly correspond to resilience of the recovery type.

In the analyzed municipalities, the recovery resilience arrangement has often been observed through the respondents' answers. It is the most substantial element in all arrangements. Nevertheless, it differs between municipalities in terms of the dimensions of the analysis.

In the case of the actors' dimensions, most respondents have stated that the dominant role in extreme weather events management is reserved for the rescue services (firefighting units). Moreover, the system is pretty stable in that respect-the same actors remain active, and new institutions rarely appear. The interviewees also stated that the management arrangement is rather closed. Cooperation is effective between those actors with a solid institutional background-firefighters, the municipal office, the police. In terms of the actors' dimensions, the recovery resilience type has been strongest in Krzyż Wielkopolski $(56 \%)$ and Szamotuły $(61 \%)$.

The recovery-type resilience arrangement is evident when analyzing the resources dimension in Szamotuły (67\%) and Nowy Tomyśl (64\%). Interviewees in these towns stated that the rescue services should receive more funds. However, these institutions are already well-funded from local budgets (according to the respondents). Still, they are also seeking additional resources from outside, but this is not a standard issue. Actors are aware that there are other solutions to cope with extreme weather events in terms of preparation or education, and sometimes they will use them, but to a limited extent. These solutions involve participation in the preparation of emergency plans.

The norms dimension is dominated by recovery-type resilience in Krzyż Wielkopolski $(67 \%)$ and Nowy Tomyśl (50\%). The interviewees stated that their functioning regulations remain relatively stable and are not often included when consulting on new rules. However, when it does happen, the voices of local actors involved in extreme weather events management are, in most cases, unheard.

The recovery-type resilience arrangement within the discourses dimension appears to be dominant in Krzyż Wielkopolski (50\%). The respondents here are looking at dealing with extreme weather events in terms of focusing on guaranteeing that the infrastructure will continue to function even after the occurrence of an event. Interviewees feel well prepared and can cope with those extremes recognized as an actual threat. They consider that the focus should remain on those activities already undertaken, while innovations are considered to be an interesting addition to the scope of activities.

An important distinguishing feature is the second component of the local risk management arrangement. The municipalities focusing on rescue operations were inclined to use complex engineering solutions to stop the effects of events or soft actions, ensuring that the impact was not severe. In the first case, an arrangement composed predominantly of recovery resilience, supplemented with resistance, has been established.

Resistance-type resilience, as the second most substantial element of local extreme weather events resilience arrangements within the actors' dimension, is mainly observed in Krzyż Wielkopolski (31\%) and Kórnik (38\%). Interviewees stated that the institutions responsible for infrastructure and municipal office are the most critical factors when dealing with extreme weather events. This is seen as a stable and working system.

In Krzyż Wielkopolski and in Kórnik, where the second strongest element of local arrangements is the resources dimension of resistance ( $31 \%$ and $45 \%$, respectively), the interviewees have pointed out a need to increase funds for infrastructure investments. At the same time, they have underlined that in terms of human resources, they have enough people to cope with extremes, and no changes are needed in this respect. Moreover, the respondents expressed their firm belief that the solutions used to deal with extreme weather events are the only effective ones, and no different measures are needed. 
The norms dimension is dominated by resistance resilience in Szamotuły (47\%) and Kórnik (41\%), even though, in terms of the arrangements of each municipality, resistance is the second most visible resilience type after recovery. Nevertheless, respondents whose statements were recognized as resistance in this dimension have focused on the stability of the formal aspects of their functioning in extreme weather events management. Moreover, they have underlined that they do not influence regulations and that there are only a few local rules that mainly refer to infrastructure management.

Interviewees from Krzyż Wielkopolski and Kórnik most often expressed the resilience resistance type of response within the discourses dimension (20\% and 19\%, respectively). Nonetheless, for all studied municipalities, resistance was the least recognized local resilience arrangement type in terms of discourse. The actors in these areas stated that municipalities should focus their activities on building a resistant infrastructure so that extreme weather events would have no consequences for local communities. Moreover, respondents stated that weather events are not a threat for their municipalities, as they use the best possible solutions, while implementing innovative measures may cause more harm than good.

As the latter element completes the imaging of local institutions' activities and determines whether to adopt a different approach, the second local resilience arrangement, composed of dominant recovery resilience and supplemented with creativity resilience, was observed.

As the second most substantial element in a local arrangement within the actors' dimension, the creativity resilience type of response is observed in the municipalities of Kórnik (29\%) and Nowy Tomyśl (21\%). Interviewees whose statements were recognized as a creativity resilience type focused on including new institutions in the local extreme weather events management system and emphasized strong cooperation between all actors.

When considering the resources dimension, creativity-type resilience as a strong component of the local arrangements was observed in Krzyż Wielkopolski (27\%) and Kórnik (30\%). Respondents stated that more funds should be allocated to education and training as potential measures for coping with the risk of extreme weather events. The interviewees also declared that they often participated in outside projects for these purposes. Moreover, knowledge resource, based on experience, has been underlined as an element that influences the way municipalities act regarding the risk of extreme weather events.

In the case of the norms dimension, creativity resilience, as a solid local arrangement component, is visible in Nowy Tomyśl (20\%) and Kórnik (24\%). The actors interviewed declared that they influenced the forming of regulations regarding extreme weather events management; there are also local regulations addressing the issue. The respondents reported constant changes in terms of regulations.

Within the discourses dimension, in two municipalities, Szamotuły and Nowy Tomyśl, a creativity-type resilience arrangement was mainly expressed by respondents: 55\% in Szamotuły and 54\% in Nowy Tomyśl. The interviewees declared that in their opinion, extreme weather events present a severe threat; therefore, as it is impossible to protect areas against the consequences of extremes, the municipalities should adapt based on their previous experiences. They also expressed a strong belief that local inhabitants should be included in the adaptation activities, through information, education, and training. Moreover, respondents have pointed out that environmentally friendly activities could be of benefit in the adaptation to extreme weather events and often offer better solutions than traditional investment in infrastructure (i.e., a rainwater sewage system).

Local extreme weather risk management arrangements, as observed in the analyzed municipalities, are shown in Figure 3. The four dimensions of the analysis (actors, resources, norms, and discourses) are compiled to illustrate the result for the whole local arrangement. The figures consist of answers given by the respondents within each dimension and averaged. The x-axis shows the percentage saturation of dimensions, with recognized resilience types forming local management resilience arrangements to extreme weather events. 


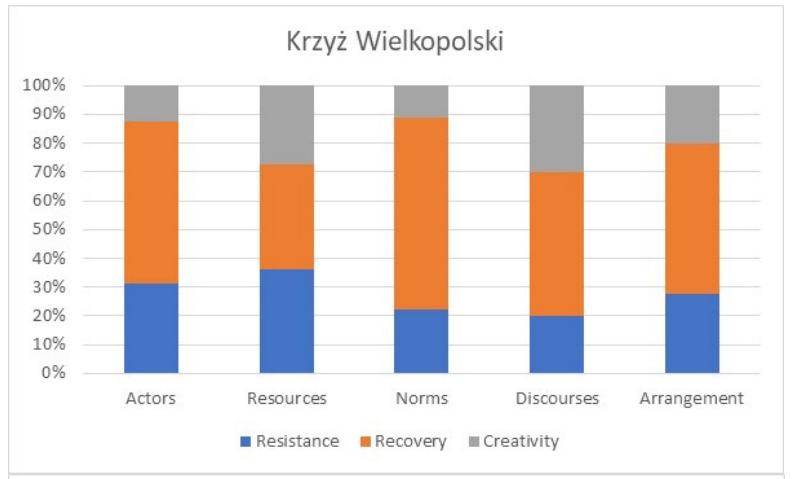

Kórnik

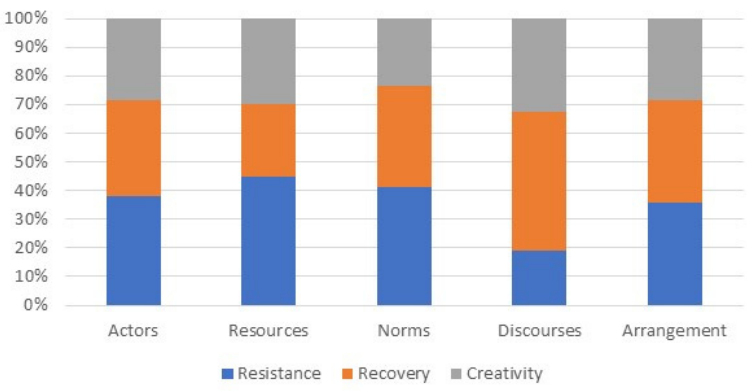

(a)
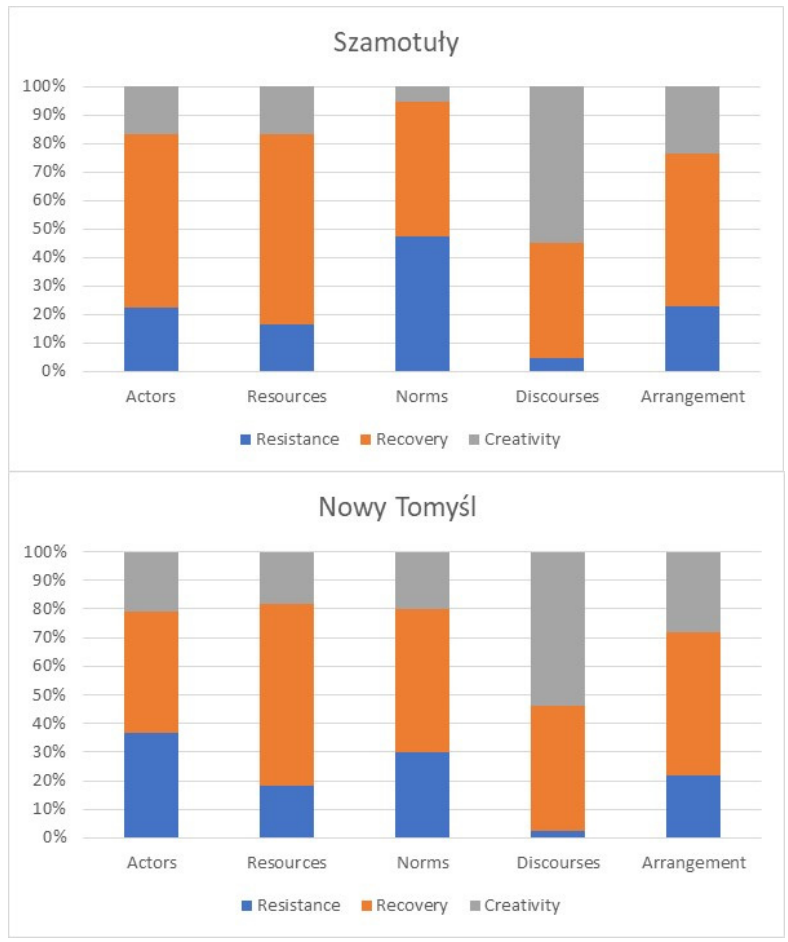

(b)

Figure 3. Local extreme weather risk management arrangements in studied municipalities, including the presentation of arrangements within the dimensions of the policy arrangements approach and for the whole municipality: (a) municipalities with an arrangement dominated by recovery resilience, with an inclination toward resistance (Krzyż Wielkopolski and Kórnik); (b) municipalities with an arrangement dominated by recovery resilience, with an inclination toward creativity (Szamotuły and Nowy Tomyśl).

\subsection{Extreme Weather Events Exposure and Local Adaptation Arrangements}

It can be concluded that greater exposure to extreme weather events contributes to the development of arrangements where resilience dominated by recovery, following the resistance-type response, is adopted. On the other hand, the municipalities least exposed to extreme weather events show a local arrangement composed of resilience, also dominated by recovery, but with a significant role of resilience in terms of the creativity-type response. For example, among the researched municipalities, Krzyż Wielkopolski, together with Kórnik, are mainly affected by extreme rainfall and heatwaves. On the other hand, the municipalities of Szamotuły and Nowy Tomyśl had the least experience of heavy rainfall and heatwaves.

In the municipality of Krzyż Wielkopolski, which was affected by the highest number of days with extreme rainfall in the analyzed period (109 days in 2010-2016), the activities were referred to as recovery, with significant input from resistance resilience. In the municipality of Kórnik (92 days), the second-highest in terms of extreme rainfall instances, recovery is also most clearly manifested, supplemented by resistance. Among the analyzed municipalities, these two (Krzyż Wielkopolski and Kórnik) were also affected mainly by heatwaves. In Kórnik, the mean number of days with heatwaves within the research period reached 15.7. In the municipality of Krzyż Wielkopolski, this number reached 15.4.

The resilience arrangements in the Szamotuły municipality, which was least exposed to extreme weather events (78 days with excessive rainfall and 12.0 days on average of heatwaves within the research period of 2010-2016), also focused on recovery type, but with a much more significant presence of creativity. Similarly, the local arrangements for actions related to the threat of meteorological extremes can be observed in the second-least 
exposed municipality among the analyzed areas-Nowy Tomyśl (84 days with extreme rainfall and 13.6 days on average of heat waves within the research period of 2010-2016). Here, the activities that are part of the recovery process are complemented by activities characteristic of creativity. The main findings of the research are summarized in Table 6.

Table 6. Summary of the main findings of the research.

\begin{tabular}{|c|c|}
\hline Analyzed Issues & Main Findings \\
\hline \multirow{6}{*}{ Extreme weather events } & $\begin{array}{c}\text { The period of 2010-2016 was more severe than 1981-2010 in terms of extreme } \\
\text { rainfall and heatwaves }\end{array}$ \\
\hline & The number of days with extreme rainfall was higher by 2 to $25 \%$ \\
\hline & Maximum daily precipitation was higher by 24 to $43 \%$ \\
\hline & Precipitation total from extreme rainfall was higher by 20 to $43 \%$ \\
\hline & The mean number of hot days was higher by 60 to $73 \%$ \\
\hline & The mean maximum temperature was higher by 0.4 to $0.7^{\circ} \mathrm{C}$ \\
\hline \multirow{4}{*}{$\begin{array}{l}\text { Local resilience } \\
\text { arrangements }\end{array}$} & The dominating component of each set of local arrangements is recovery resilience \\
\hline & $\begin{array}{l}\text { In general, two different local resilience arrangements have emerged: (a) with the } \\
\text { domination of recovery and a strong component of resistance; (b) with the } \\
\text { domination of recovery and a strong component of creativity }\end{array}$ \\
\hline & Creativity resilience was mainly observed within the discourses dimension \\
\hline & Resistance resilience was mainly observed in the resources and norms dimensions \\
\hline \multirow{3}{*}{$\begin{array}{l}\text { Extreme meteorological events exposure and } \\
\text { emergence of resilience arrangements }\end{array}$} & $\begin{array}{l}\text { Exposure to extreme weather events results in the emergence of specified local } \\
\text { resilience arrangements }\end{array}$ \\
\hline & $\begin{array}{l}\text { Within those municipalities more exposed to extremes, an arrangement composed } \\
\text { of dominating recovery resilience and resistance resilience has been observed }\end{array}$ \\
\hline & $\begin{array}{l}\text { Within the municipalities least exposed to extremes, an arrangement composed of } \\
\text { dominating recovery resilience and creativity resilience has been observed }\end{array}$ \\
\hline
\end{tabular}

\section{Discussion}

The above analysis shows that the management of extreme weather events in Polish municipalities concentrates on rescue activities. This is different from other studies analyzing Polish cases with a similar methodology, dealing with natural hazards [16]. Those studies showed a solid commitment to engineering and infrastructural activities, which are understood here as an element of resistance-type resilience.

The problem of local municipalities and their resilience is widely analyzed across the globe. Nevertheless, as Scherzer et al. indicate, there is a need to introduce a baseline first. This initial measure can be used to compare municipalities as a way to look at how resilience changes [87]. This research aims to meet this need, as applied to Poland. What needs to be emphasized is that studies show that resilience increases, in the sense of better preparation for an extreme event, when the societal impacts of natural disasters decrease [88]. In that context, the results obtained in this research show that where fewer extremes occurred, arrangements where recovery resilience, supplemented with creativity resilience, emerged. This would suggest that this type of arrangement gives more potential to reduce the adverse consequences of meteorological events.

This paper, presenting research on local resilience arrangements for responses to extreme weather events in selected municipalities in the Wielkopolska region in Poland, attempts to explore how local communities deal with the risks associated with meteorological events. Before 2007, when the Act regarding crisis management in Poland was adopted [13], and before the establishment of the Government Security Center and its reorganization in 2011 [89], extreme weather events were not of interest to research and administrative unit analyses. 
Moreover, the period of 2010-2016, as has been shown, was more extreme in terms of meteorological events than the previous years. Before this period, although it may seem surprising, no specific research was carried out regarding the functioning of local municipalities in the context of weather extremes, as these were generally perceived not to pose a significant threat. Moreover, the various levels of government did not address the consequences of climate change, such as extreme weather events, including the need for administrative action at multiple levels, as climate change was not perceived through the prism of an actual threat. The literature points to a lack of awareness and knowledge as the reasons for this $[90,91]$. Over time, adaptation plans regarding climate change began to emerge, but they only referred to their necessity for the largest cities in the country and not for small towns [91], which are the subject of this article. This study attempts to show the shape of dealing with extreme weather events in small towns. It does not evaluate the applied solutions but instead identifies the current state of contingency planning as a starting point for future research, and indicates some problems that are currently an issue for local extreme weather events resilience arrangements.

During this research, respondents reported several problems related to the functioning of local risk management systems concerning extreme weather events. The element that raised the most doubts turned out to be warning messages about weather events. Research dealing with resilience issues often mentions the problem of proper communication and raising community awareness [92]. The actors assessed these issues very ambiguously. On the one hand, they said that communication was essential and constituted an important element of the crisis management system in municipalities.

On the other hand, they found that the quality of these messages made them useless. Such messages concern a vast area, and their verifiability is therefore small. The respondents also noted that an excess of such information might also be a threat because there may be a situation regarding omitting and not paying attention to messages in the face of a frequent lack of verifiability. Moreover, the interviewees noted that individuals often do not understand the warning messages or do not take them into account as personally relevant. Here, the problem was seen to be rooted in the education and preparation of the inhabitants. Likewise, there was disagreement about the addressees of such warnings-whether they should be institutional actors or individuals (households).

The interlocutors disagreed on the organization of municipal crisis management centers. Often, they are not established in municipalities (it is not obligatory), and the duties of crisis management rest on the shoulders of a single employee. Moreover, they are often only a part-time employee of the municipal office. The opinions of the interviewees were very different. Some pointed to the necessity of creating municipal centers; others noted that there was no such need in small communities.

There was also the issue of competency disputes between municipal offices and county offices in terms of crisis measures. Representatives of actors from both levels of local government administration accused each other of a reluctance to accept responsibility and to take action (due to the related costs and potential legal liability). Actors from the county administration noted that municipalities often did not want to cooperate, declaring a belief that they had much better knowledge of their administration area, rejecting the assistance of county crisis management centers. Faced with these problems, actors often proposed creating a single institution, centralizing crisis management competencies at a higher level.

Several problems concerning risk management, related to meteorological hazards in municipalities, were observed in the conducted research. These issues were indicated by the interlocutors, regardless of the local resilience arrangement. Therefore, it is not easy to suggest which course of action would be the best in the given municipalities. Verifying the effectiveness of the activities carried out under individual local resilience arrangements is the subject of interest and of further research by the authors. However, based on the obtained answers, it can be concluded that actors were more inclined toward solutions characteristic of creativity resilience at the discursive level. 
Furthermore, a large proportion of the interviewees emphasized the need to implement solutions other than those currently applied, emphasizing educational activities and activities involving local communities. Hence, it can be assumed that, based on expert knowledge, the expected resilience arrangement is one with a more significant role for creativity resilience. In the authors' opinion, recovery resilience will remain the most substantial element of local arrangements. Still, its role-to a large extent, the necessity for intervention by emergency services-could be diminished by strengthening those solutions typical of creativity-type resilience. This is mainly a question of improving the quality of meteorological warnings and raising residents' awareness regarding taking appropriate actions in response to the information provided about the threat. Therefore, it seems that municipalities that struggle with weather extremes should develop their management systems while considering creativity resilience.

Nevertheless, a change in this direction has only been observed among municipalities that are less affected by extreme weather events. On the other hand, the resistance resilience component is visible among the most exposed municipalities. Whether the applied solutions are effective or if the approach should be changed will be indicated in future studies by the authors, which will consider the costs incurred related to the consequences of extreme weather events.

The literature dealing with resilience, especially when applying this concept in research, points to specific difficulties associated with quantification [23]. Nevertheless, research shows several elements that influence resilience. These include attitudes and values [93], community involvement [94], communication and information [95], leadership [95], and resource dependency [20]. The factors mentioned above come from research treating the concept of resilience in various ways. While some of the studies refer to resilience, similarly to the nature of individual types of resilience, they emphasize the strength (or weakness) of resilience [96].

Many studies have undertaken different methods to analyze resilience. For example, Cai et al. have indicated that $39.7 \%$ use qualitative methods and $39.1 \%$ concentrate on quantitative ways of resilience measurement [92]. This paper on Polish municipalities' resilience in terms of extreme weather events attempts to unify both methods, focusing on quantitative meteorological data and working with qualitative social data.

Moreover, various approaches are noted in the case of the term resilience. Different ways of looking at the resilience issue in terms of the studies mentioned above also result from implementation time, as the resilience concept has evolved over many years. The cause of this inconsistency is that the starting points for research are in different fields of science, which, together with different theoretical backgrounds, results in adopting different conceptual perspectives. Nevertheless, the factors influencing the type of resilience identified in the research are reflected in the various dimensions of the analytical framework used in this study: norms, attitudes, and values [93], and are a part of one dimension-norms within the policy arrangement approach. Likewise, resource dependency [20], communication, and information [95] fit into the resource dimension. Social commitment [94] and leadership [95] are part of the actors' dimension.

It should be noted that some of the aforementioned resilience-building elements link the different dimensions of the policy arrangements approach. However, the literature where this analytical framework is used allows this link to happen. It is clear that this is normal, as each dimension has points of contact with the others [67]. Thus, a typical area that can be analyzed from the perspective of two dimensions (resources and discourses) is, for example, communication and information [95]. The model can be treated as a resource for controlling communication methods or, in other words, discursive power [67].

\section{Conclusions}

The hypothesis stated in this study, that greater exposure to extreme weather events would inform local arrangements dominated by resistance-type resilience, has been negatively verified. Regardless of the frequency of extreme weather events, local systems focus 
on the appropriate rescue actions for the resilience recovery type, instead of on resistance resilience methods. The most important institution is the fire brigades, which can undertake ad hoc interventions and act throughout an event. According to many respondents, it is impossible to prepare thoroughly. However, one can improve protection during events by strengthening the emergency services, so that the local system could function with the least disruption. Complementing this picture of local municipalities' activities is the second component of local risk management arrangements, related to the consequences of extreme meteorological events. This was decisive in terms of taking specific actions. High exposure to extreme weather events resulted in the development of arrangements that take measures characteristic of resilience in the form of resistance-engineering, more than interfering with, the structural elements of the environment. Interviewees underlined the role of strong institutional actors who were in possession of regulatory and financial or material resources as the municipal office. They are intended to introduce traditional protective measures, such as installing rainwater sewage systems.

On the other hand, the smaller number of experiences resulted in the possibility of developing arrangements that lean more toward softer solutions, focused on the preparation of local people rather than on infrastructure. In that respect, respondents pointed out the roles of proper education, understanding risks, and issuing meteorological warnings. Moreover, preparation and the ongoing verification of rescue and evacuation plans in these local arrangements is an important feature of local systems. Moreover, regardless of the actions taken and the stated opinions of local actors, this analysis of meteorological data indicates that in the studied municipalities, problems related to extreme weather events do exist. What is more, the number of extreme events is increasing compared to the reference periods, and it is anticipated that there will be even more of them in the future. Furthermore, changes related to infrastructure development and spatial development increase a community's vulnerability to the effects of extreme weather events. Hence, regardless of the chosen path, it is necessary to undertake adaptation measures and ensure that the implemented measures make local systems resilient in the best possible way, taking into account local conditions.

Thanks to this research, it was possible to identify weaknesses in local risk management systems, as related to extreme weather events. Carrying out similar research in other regions of the country or, taking into account national specificity, conducting research based on a similar methodology in other countries would make it possible to find areas that negatively affect the safety of local communities and, then, to evaluate the methods implemented. This would ultimately improve the effectiveness of local communities' risk management systems related to extreme weather events.

Author Contributions: Conceptualization, A.C.; methodology, A.C. and I.P.; software, A.C. and I.P.; formal analysis, A.C.; investigation, A.C.; data curation, I.P. and A.C.; writing-original draft preparation, A.C., I.P. and M.K.; writing-review and editing, M.K., D.G., I.P., A.C.; visualization, I.P. and A.C.; funding acquisition, A.C. All authors have read and agreed to the published version of the manuscript.

Funding: This research was funded by the NATIONAL SCIENCE CENTRE (Narodowe Centrum Nauki), grant number UMO-2014/15/N/HS6/04129.

Informed Consent Statement: Not applicable.

Data Availability Statement: Not applicable.

Acknowledgments: The first author wishes to thank Piotr Matczak and Agnieszka Jeran from Adam Mickiewicz University in Poznan, Poland, for the supervision and crucial revisions of the Ph.D. dissertation, which contributed to this paper.

Conflicts of Interest: The authors declare no conflict of interest. 


\section{Appendix A}

Table A1. Appendix A presents the interviewed respondents' occupations in the selected municipalities.

\begin{tabular}{ccc}
\hline Municipality & Respondent Position & Interview Date \\
\hline & Crisis management officer (municipality) & December 2017 \\
& Volunteer Fire Department officer & December 2017 \\
Kórnik & Municipal police officer & December 2017 \\
& Local journalist & December 2017 \\
& Village administrator & December 2017 \\
\hline & Crisis management officer (municipality) & February 2018 \\
& Volunteer Fire Department officer & February 2018 \\
& Crisis management officer (county) & February 2018 \\
Krzyż Wielkopolski & State Fire Department officer & February 2018 \\
& Local journalist & February 2018 \\
\hline \multirow{5}{*}{ Nowy Tomyśl } & State Fire Department officer & February 2018 \\
& Local journalist & February 2018 \\
& Crisis management officer (municipality) & February 2018 \\
& Municipal police officer & February 2018 \\
& Supralocal journalist & January 2018 \\
\hline & Crisis management officer (municipality) & February 2018 \\
& Crisis management officer (county) & February 2018 \\
& State Fire Department officer & February 2018 \\
& Municipal police officer & February 2018 \\
& Local journalist & February 2018 \\
\hline
\end{tabular}

\section{Appendix B}

Table A2. Appendix B presents the questions stated during the in-depth interviews, organized within the dimensions of the policy arrangements approach, and an overview of answers according to the type of resilience a statement has been qualified for.

\begin{tabular}{|c|c|c|c|c|c|}
\hline & & & Overview of $\mathrm{Ob}$ & ined Answers Representing Diff & ent Resilience Types \\
\hline & & Interview Questions & Resistance & Recovery & Creativity \\
\hline 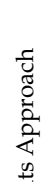 & & $\begin{array}{l}\text { What institutions are involved in } \\
\text { extreme weather events (EWE) } \\
\text { activities? To what extent are they } \\
\text { the same institutions? }\end{array}$ & $\begin{array}{l}\text { The most critical role in the } \\
\text { municipality is played by the } \\
\text { services responsible for the } \\
\text { condition of the anti-loss } \\
\text { infrastructure/devices-and } \\
\text { this has not changed for years }\end{array}$ & $\begin{array}{l}\text { This is mainly emergency } \\
\text { services. New institutions have } \\
\text { emerged, but they are doing } \\
\text { little about EWE }\end{array}$ & $\begin{array}{l}\text { New institutions are constantly } \\
\text { emerging who want to work with } \\
\text { EWE; they are often institutions } \\
\text { promoting } \\
\text { non-technical/non-infrastructural } \\
\text { solutions }\end{array}$ \\
\hline 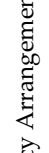 & 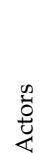 & $\begin{array}{l}\text { To what extent should other new } \\
\text { institutions be involved in activities } \\
\text { related to EWE? }\end{array}$ & $\begin{array}{c}\text { The way it works now is } \\
\text { acceptable; no one else should } \\
\text { be involved }\end{array}$ & $\begin{array}{l}\text { You can invite other/new } \\
\text { institutions to cooperate, but it } \\
\text { is not necessary }\end{array}$ & $\begin{array}{l}\text { You have to involve whoever you } \\
\text { can, regardless of whether it is } \\
\text { unique or atypical, and if you have } \\
\text { to, you should give up cooperation } \\
\text { with some institutions }\end{array}$ \\
\hline 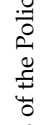 & & $\begin{array}{l}\text { How is the cooperation between } \\
\text { institutions involved in activities } \\
\text { related to EWE shaped? }\end{array}$ & $\begin{array}{l}\text { Everyone does their own thing, } \\
\text { only, when necessary, we } \\
\text { cooperate }\end{array}$ & $\begin{array}{l}\text { We work well with those with } \\
\text { whom we have been operating } \\
\text { for years, while the new ones } \\
\text { would rather work alone }\end{array}$ & $\begin{array}{l}\text { Without intensive cooperation on } \\
\text { an equal footing, it would be } \\
\text { challenging to work with EWE }\end{array}$ \\
\hline 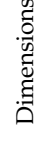 & & $\begin{array}{l}\text { Which institutions play the most } \\
\text { critical role in actions towards the } \\
\text { EWE? }\end{array}$ & $\begin{array}{l}\text { The most important are } \\
\text { institutions dealing with } \\
\text { infrastructure, such as the } \\
\text { municipal office }\end{array}$ & $\begin{array}{l}\text { The most important are } \\
\text { emergency services, the police, } \\
\text { fire brigades, municipal police; } \\
\text { they are the most important } \\
\text { when it comes to EWE }\end{array}$ & $\begin{array}{l}\text { Each institution is fundamental, but } \\
\text { non-governmental organizations } \\
\text { that educate residents about EWE } \\
\text { are essential here }\end{array}$ \\
\hline
\end{tabular}


Table A2. Cont.

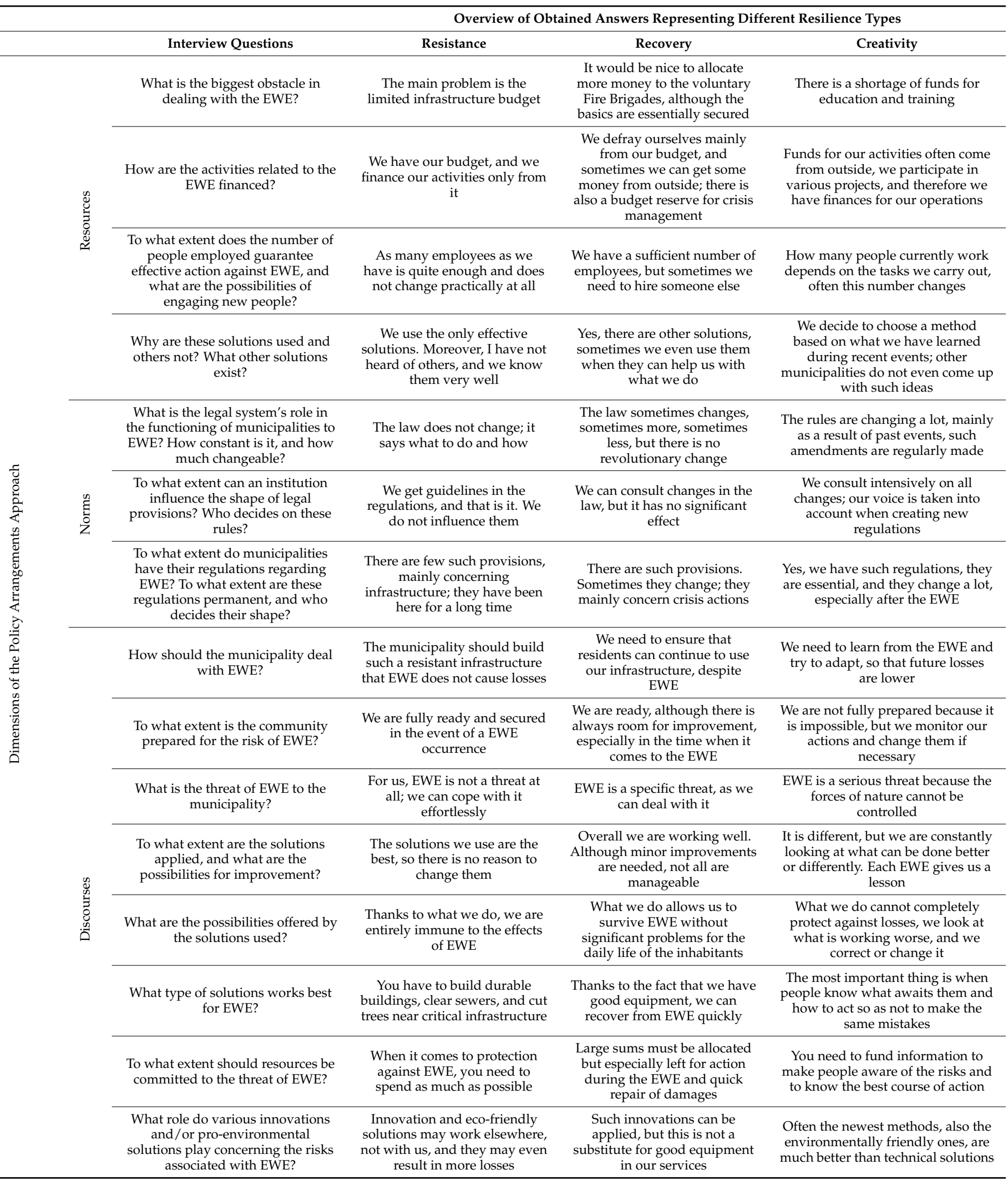




\section{References}

1. IPCC; Core Writing Team; Pachauri, R.K.; Meyer, L.A. Climate Change 2014: Synthesis Report. Contribution of Working Groups I, II and III to the Fifth Assessment Report of the Intergovernmental Panel on Climate Change; Gian-Kasper Plattner: Geneva, Switzerland, 2014.

2. Voss, M.; Wagner, K. Learning from (small) disasters. Nat. Hazards 2010, 55, 657-669. [CrossRef]

3. Feldman, M.S.; Pentland, B.T. Reconceptualizing Organizational Routines as a Source of Flexibility and Change. Adm. Sci. Q. 2003, 48, 94. [CrossRef]

4. Glickman, T.S. (Ed.) Glossary of Meteorology; American Meteorological Society: Boston, MA, USA, 2000; ISBN 9781878220349.

5. Beniston, M. An overview of extreme climatic events in Switzerland: Implications for assessing economic damages and costs. In The Coupling of Climate and Economic Dynamics; Haurie, A., Viguier, L., Eds.; Springer: Dordrecht, The Netherlands, 2005; pp. 321-340.

6. Bates, B.C.; Kundzewicz, Z.W.; Wu, S.; Palutikof, J.P. Climate Change and Water; IPCC Secretariat: Geneva, Switzerland, 2008; ISBN 9789291691234.

7. Djalante, R.; Holley, C.; Thomalla, F. Adaptive governance and managing resilience to natural hazards. Int. J. Disaster Risk Sci. 2011, 2, 1-14. [CrossRef]

8. Pińskwar, I. Complex changes of extreme precipitation in the warming climate of Poland. Int. J. Climatol. 2022, 42, 817-833. [CrossRef]

9. Pinskwar, I.; Chorynski, A.; Kundzewicz, Z.W. Severe drought in the spring of 2020 in Poland-More of the same? Agronomy 2020, 10, 1646. [CrossRef]

10. Graczyk, D.; Kundzewicz, Z.W.; Choryński, A.; Førland, E.J.; Pińskwar, I.; Szwed, M. Heat-related mortality during hot summers in Polish cities. Theor. Appl. Climatol. 2019, 136, 1259-1273. [CrossRef]

11. Komenda Główna Państwowej Straży Pożarnej. Krajowy System Ratowniczo-Gaśniczy; KG PSP: Warszawa, Poland, 2016.

12. Dumieński, G.; Mruklik, A.; Tiukało, A.; Bedryj, M. The Comparative Analysis of the Adaptability Level of Municipalities in the Nysa Kłodzka Sub-Basin to Flood Hazard. Sustainability 2020, 12, 3003. [CrossRef]

13. Sejm. Ustawa z dnia 26 Kwietnia 2007 o Zarzadzaniu Kryzysowym; Dz.U. 2007 Nr 89 poz. 590; Sejm: Warszawa, Poland, 2007.

14. Matczak, P.; Abgarowicz, G. Country Study: Poland, Report for ANVIL Project; Adam Mickiewicz University: Poznan, Poland, 2013.

15. Abgarowicz, G.; Cebul, K.; Abgarowicz, I.; Wachnik, M.; Plasota, T.; Połeć, B.; Napiórkowski, M. (Eds.) Pamięć Przyszłości. Analiza Ryzyka dla Zarządzania Kryzysowego; Wydawnictwo CNBOP-PIB: Józefów, Poland, 2015; ISBN 978-83-61520-22-1.

16. Matczak, P.; Lewandowski, J.; Chorynski, A.; Szwed, M.; Kundzewicz, Z.W. Stability and Change of Flood Risk Governance in Poland; Kundzewicz, Z., Stoffel, M., Niedźwiedź, T., Wyżga, B., Eds.; Flood Risk in the Upper Vistula Basin. GeoPlanet: Earth and Planetary Sciences; Springer: Cham, Switzerland, 2016. [CrossRef]

17. Folke, C. Resilience: The emergence of a perspective for social-ecological systems analyses. Glob. Environ. Chang. 2006, 16, 253-267. [CrossRef]

18. Omand, D. Developing national resilience. RUSI J. 2005, 150, 14-18. [CrossRef]

19. Kimhi, S.; Shomai, M. Community resilience and the impact of stress: Adult response to Israel's withdrawal from Lebanon. J. Community Psychol. 2004, 32, 439-451. [CrossRef]

20. Adger, W.N. Social and ecological resilience: Are they related? Prog. Hum. Geogr. 2000, 24, 347-364. [CrossRef]

21. Breton, M. Neighborhood Resiliency. J. Commun. Pract. 2001, 9, 21-36. [CrossRef]

22. Aguirre, B.E. On the Concept of Resilience. 2006. Available online: http://udspace.udel.edu/handle/19716/2517 (accessed on 30 November 2021).

23. Maguire, B.; Hagan, P. Disasters and communities: Understanding social resilience. Aust. J. Emerg. Manag. 2007, 22, 16-20.

24. Hegger, D.L.T.; Driessen, P.P.J.; Wiering, M.; Van Rijswick, H.F.M.W.; Kundzewicz, Z.W.; Matczak, P.; Crabbe, A.; Raadgever, G.T.; Bakker, M.H.N.; Priest, S.J.; et al. Toward more flood resilience: Is a diversification of flood risk management strategies the way forward? Ecol. Soc. 2016, 21, 52. [CrossRef]

25. De Bruijn, K.; Buurman, J.; Mens, M.; Dahm, R.; Klijn, F. Resilience in practice: Five principles to enable societies to cope with extreme weather events. Environ. Sci. Policy 2017, 70, 21-30. [CrossRef]

26. Saniotis, A.; Hansen, A.; Kralik, D.; Arbon, P.; Nitschke, M.; Bi, P. Building community resilience to heatwaves in South Australia. Trans. R. Soc. South Aust. 2015, 139, 113-120. [CrossRef]

27. Turnbull, M.; Sterrett, C.L.; Amy, H. Toward Resilience: A Guide to Disaster Risk Reduction and Climate Change Adaptation; Practical Action Publishing Ltd., Bourton on Dunsmore: Rugby, UK, 2013; ISBN 978-1-78044-786-5.

28. Chelleri, L.; Waters, J.J.; Olazabal, M.; Minucci, G. Resilience trade-offs: Addressing multiple scales and temporal aspects of urban resilience. Environ. Urban. 2015, 27, 181-198. [CrossRef]

29. Zhang, X.; Li, H. Urban resilience and urban sustainability: What we know and what do not know? Cities 2018, 72, 141-148. [CrossRef]

30. Borsekova, K.; Nijkamp, P.; Guevara, P. Urban resilience patterns after an external shock: An exploratory study. Int. J. Disaster Risk Reduct. 2018, 31, 381-392. [CrossRef]

31. Alexander, M.; Priest, S.; Mees, H. A framework for evaluating flood risk governance. Environ. Sci. Policy 2016, 64, 38-47. [CrossRef]

32. McEvoy, D.; Matczak, P.; Banaszak, I.; Chorynski, A. Framing adaptation to climate-related extreme events. Mitig. Adapt. Strateg. Glob. Chang. 2010, 15, 779-795. [CrossRef] 
33. Dumieński, G.; Tiukało, A. Ocena podatności systemu społeczno-ekologicznego zagrożonego powodzią. Prace Stud. Geogr. 2016, 61, 7-23.

34. Matczak, P.; Lewandowski, J.; Choryński, A.; Szwed, M.; Kundzewicz, Z.W. Flood Risk Governance in Poland: Looking for Strategic Planning in a Country in Transition (Report D3.6); STAR-FLOOD Consortium: Utrecht, The Netherlands, 2016; ISBN 978-94-91933-09-7.

35. Driessen, P.P.J.; Hegger, D.L.T.; Kundzewicz, Z.W.; van Rijswick, H.F.M.W.; Crabbé, A.; Larrue, C.; Matczak, P.; Pettersson, M.; Priest, S.; Suykens, C.; et al. Governance Strategies for Improving Flood Resilience in the Face of Climate Change. Water 2018, 10, 1595. [CrossRef]

36. Matczak, P.; Hegger, D. Improving flood resilience through governance strategies: Gauging the state of the art. Wiley Interdiscip. Rev. Water 2021, 8, e1532. [CrossRef]

37. Liefferink, D.; Wiering, M.; Crabbé, A.; Hegger, D. Explaining stability and change. Comparing flood risk governance in Belgium, France, the Netherlands, and Poland. J. Flood Risk Manag. 2018, 11, 281-290. [CrossRef]

38. Masik, G.; Gajewski, R. Working towards urban capacity and resilience strategy implementation: Adaptation plans and strategies in Polish cities. Cities 2021, 119, 103381. [CrossRef]

39. Wziątek-Kubiak, A.; Pęczkowski, M. Strengthening the Innovation Resilience of Polish Manufacturing Firms in Unstable Environments. J. Knowl. Econ. 2021, 12, 716-739. [CrossRef]

40. Matczak, P.; Kundzewicz, Z.W.; Szwed, M.; Choryński, A.; Lewandowski, J. Doing more while remaining the same? Flood risk governance in Poland. J. Flood Risk Manag. 2017, 11, 239-249. [CrossRef]

41. Listwan-Franczak, K.; Franczak, P.; Działek, J.; Biernacki, W. Natural disaster insurance as non-technical means of protection against floods in Poland in the light of empirical research. Prace Stud. Geogr. 2016, 61, 101-122.

42. Lucini, B. Disaster Resilience from a Sociological Perspective; Springer: Cham, Switzerland, 2014; ISBN 978-3-319-04737-9.

43. Jacobs, B.; Boronyak-Vasco, L.; Moyle, K.; Leith, P. Ensuring Resilience of Natural Resources under Exposure to Extreme Climate Events. Resources 2016, 5, 20. [CrossRef]

44. Rapaport, C.; Hornik-Lurie, T.; Cohen, O.; Lahad, M.; Leykin, D.; Aharonson-Daniel, L. The relationship between community type and community resilience. Int. J. Disaster Risk Reduct. 2018, 31, 470-477. [CrossRef]

45. Carpenter, S.R.; Arrow, K.J.; Barrett, S.; Biggs, R.; Brock, W.A.; Crépin, A.S.; Engström, G.; Folke, C.; Hughes, T.P.; Kautsky, N.; et al. General Resilience to Cope with Extreme Events. Sustainbility 2012, 4, 3248-3259. [CrossRef]

46. Cutter, S.L.; Ash, K.D.; Emrich, C.T. Urban-Rural Differences in Disaster Resilience. Ann. Am. Assoc. Geogr. 2016, 106, 1236-1252. [CrossRef]

47. Lai, C.H.; Liao, P.C.; Chen, S.H.; Wang, Y.C.; Cheng, C.; Wu, C.F. Risk Perception and Adaptation of Climate Change: An Assessment of Community Resilience in Rural Taiwan. Sustainbility 2021, 13, 3651. [CrossRef]

48. Linnenluecke, M.K.; Griffiths, A. Assessing organizational resilience to climate and weather extremes: Complexities and methodological pathways. Clim. Chang. 2012, 113, 933-947. [CrossRef]

49. Ahern, J. From fail-safe to safe-to-fail: Sustainability and resilience in the new urban world. Landsc. Urban Plan. 2011, 100, 341-343. [CrossRef]

50. Mees, H.; Crabbe, A.; Alexander, M.; Kaufmann, M.; Bruzzone, S.; Levy, L.; Lewandowski, J. Coproducing flood risk management through citizen involvement: Insights from cross-country comparison in Europe. Ecol. Soc. 2016, 21, 7. [CrossRef]

51. Beller-Simms, N.; Fillmore, L.; Metchis, K.; Ozekin, K.; Powell, E.; Brown, E. Responding to Extreme Weather and Climate Events Adaptation Strategies and Information Needs. 2013. Available online: https://cpo.noaa.gov/sites/cpo/Projects/SARP/ Extreme_Weather_Factsheet_Compendium.final7.19.13.pdf (accessed on 30 November 2021).

52. Kurowska-Łazarz, R.; Szulc, W.; Woźniak, B.; Piotrowska, M.; Drożdżyńska, J. Vademecum. Pomiary i Obserwacje Meteorologiczne ; Instytut Meteorologii i Gospodarki Wodnej-Państwowy Instytut Badawczy: Warszawa, Poland, 2015.

53. Yin, R.K. Applications of case study research. Appl. Soc. Res. Methods Ser. 2013, 34, 173. [CrossRef]

54. Richards, L. Handling Qualitative Data: A Practical Guide, 2nd ed.; Sage Publications: London, UK, 2009; ISBN 0-7619-4259-9.

55. $\mathrm{Wu}, \mathrm{H}$. Advancing resilience post-disaster. In Risk Communication and Community Resilience; Kar, B., Cochran, D.M., Eds.; Routledge: Abingdon, UK; New York, NY, USA, 2019; ISBN 978-1-138-08821-4.

56. Babbie, E.R. The Practice of Social Research, 5th ed.; Cengage: Boston, MA, USA, 2021; ISBN 9780357360767.

57. Marvasti, A.B. Qualitative Research in Sociology an Introduction; SAGE Publications: Thousand Oaks, CA, USA, 2003; ISBN 9780761948605

58. Choryński, A. Adaptacja Wielkopolskich Gmin do Ekstremalnych Zdarzeń Pogodowych w Świetle Koncepcji Elastyczności (Resilience). Ph.D. Thesis, Adam Mickiewicz University, Poznan, Poland, 2019. Available online: https://hdl.handle.net/10593/ 25222 (accessed on 30 November 2021).

59. Statistics Poland, Local Data Bank. Available online: https://bdl.stat.gov.pl/BDL/start (accessed on 30 November 2021).

60. Konecka-Szydłowska, B. Różnorodność w jedności. Przykład miast powiatu czarnkowsko-trzcianeckiego. Stud. Miej. 2012, 5, 129-143.

61. Poniży, L. Recreational Area Trends in the Rural-Urban Fringe: Case Study of Kórnik Gmina (Commune). Turyzm/Tourism 2010, 20,4 .

62. Zydron, A.; Antkowiak, M.; Szczepański, P. Evaluation of the execution of development strategy's objectives of city and commune of kórnik according to the habitants opinion. Studia Prace WNEiZ 2016, 46, 393-408. [CrossRef] 
63. Strategia Rozwoju Gminy Nowy Tomyśl na Lata 2021-2030. 2021. Available online: https://bip.nowytomysl.pl/Article/id,1012 .html (accessed on 20 November 2021).

64. Raport o Stanie Miasta i Gminy Szamotuły za rok 2019. 2020. Available online: https://www.bip.szamotuly.pl/m,1874,2019.html (accessed on 2 December 2021).

65. Strategia Rozwoju Miasta i Gminy Szamotuły na Lata 2014-2020. 2014. Available online: https://www.bip.szamotuly.pl/m,1033 ,strategia-rozwoju-miasta-i-gminy.html (accessed on 2 December 2021).

66. Arts, B.; Leroy, P.; van Tatenhove, J. Political modernisation and policy arrangements: A framework for understanding environmental policy change. Public Organ. Rev. 2006, 6, 93-106. [CrossRef]

67. Liefferink, D. The dynamics of policy arrangements: Turning round the tetrahedron. In Institutional Dynamics in Environmental Governance; Arts, B., Leroy, P., Eds.; Springer: Dordrecht, The Netherlands, 2006; pp. 45-68, ISBN 140205078X.

68. Kaufmann, M. Limits to change-institutional dynamics of Dutch flood risk governance. J. Flood Risk Manag. 2018, 11, 250-260. [CrossRef]

69. Hegger, D.L.T.; Driessen, P.P.J.; Dieperink, C.; Wiering, M.; Raadgever, G.T.T.; van Rijswick, H.F.M.W. Assessing stability and dynamics in flood risk governance: An empirically illustrated research approach. Water Resour. Manag. 2014, 28, 4127-4142. [CrossRef]

70. Mees, H.; Crabbé, A.; Suykens, C. Belgian flood risk governance: Explaining the dynamics within a fragmented governance arrangement. J. Flood Risk Manag. 2018, 11, 271-280. [CrossRef]

71. Kaufmann, M.; Lewandowski, J.; Choryński, A.; Wiering, M. Shock events and flood risk management: A media analysis of the institutional long-term effects of flood events in The Netherlands and Poland. Ecol. Soc. 2016, 21, 51. [CrossRef]

72. Wiering, M.A.; Arts, B.J.M. Discursive shifts in Dutch river management: "Deep" institutional change or adaptation strategy? Hydrobiologia 2006, 565, 327-338. [CrossRef]

73. Fournier, M.; Larrue, C.; Schellenberger, T. Changes in flood risk governance in France: A David and Goliath story? J. Flood Risk Manag. 2018, 11, 261-270. [CrossRef]

74. Matczak, P.; Lewandowski, J.; Choryński, A.; Szwed, M.; Kundzewicz, Z.W. Flood risk governance arrangements in Europe. PIAHS 2015, 369, 195-199. [CrossRef]

75. Folke, C. Resilience (Republished). Ecol. Soc. 2016, 21, 44. [CrossRef]

76. Mens, M.J.P.; Klijn, F.; de Bruijn, K.M.; van Beek, E. The meaning of system robustness for flood risk management. Environ. Sci. Policy 2011, 14, 1121-1131. [CrossRef]

77. De Graaf, R.; van de Giesen, N.; van de Ven, F. Alternative water management options to reduce vulnerability for climate change in the Netherlands. Nat. Hazards 2009, 51, 407-422. [CrossRef]

78. Folke, C.; Carpenter, S.R.; Walker, B.; Scheffer, M.; Chapin, T.; Rockström, J. Resilience thinking: Integrating resilience, adaptability and transformability. Ecol. Soc. 2010, 15, 62-68. [CrossRef]

79. Kafle, S.K. Integrated Community Based Risk Reduction: An Approach to Building Disaster Resilient Communities. Colombo. 2010. Available online: https:/ / www.unisdr.org/files/14348_14348SheshKafleICBRR2010.pdf (accessed on 1 November 2021).

80. Twigg, J. Characteristics of a Disaster-Resilient Community; University College London: London, UK, 2009.

81. Wardekker, J.A.; de Jong, A.; Knoop, J.M.; van der Sluijs, J.P. Operationalising a resilience approach to adapting an urban delta to uncertain climate changes. Technol. Forecast. Soc. Chang. 2010, 77, 987-998. [CrossRef]

82. Davoudi, S. Resilience: A Bridging Concept or a Dead End? "Reframing" Resilience: Challenges for Planning Theory and Practice Interacting Traps: Resilience Assessment of a Pasture Management System in Northern Afghanistan Urban Resilience: What Does it Mean in Planni. Plan. Theory Pract. 2012, 13, 299-333. [CrossRef]

83. Berkes, F.; Colding, J.; Folke, C. (Eds.) Navigating Social-Ecological Systems-Building Resilience for Complexity and Change; Cambridge University Press: Cambridge, UK, 2003.

84. Pahl-Wostl, C.; Sendzimir, J.; Jeffrey, P.; Aerts, J.; Berkamp, G.; Cross, K. Managing change toward adaptive water management through social learning. Ecol. Soc. 2007, 12, 30. [CrossRef]

85. Folke, C.; Hahn, T.; Olsson, P.; Norberg, J. Adaptive Governance of Social-Ecological Systems. Annu. Rev. Environ. Resour. 2005, 30, 441-473. [CrossRef]

86. Polish Institute of Meteorology and Water Management-National Research Institute-IMGW-PIB. Public Data Repository. Available online: https:/ / dane.imgw.pl/ (accessed on 12 December 2021).

87. Scherzer, S.; Lujala, P.; Rød, J.K. A Community Resilience Index for Norway: An Adaptation of the Baseline Resilience Indicators for Communities (BRIC). Int. J. Disaster Risk Reduct. 2019, 36, 101107. [CrossRef]

88. Davies, T.R.H.; Davies, A.J. Increasing communities' resilience to disasters: An impact-based approach. Int. J. Disaster Risk Reduct. 2018, 31, 742-749. [CrossRef]

89. Szczurek, T.; Szczurek, M. Protection of National and European Critical Iinfrastructure. Natl. Secur. Stud. 2018, 13, 205-219. [CrossRef]

90. Kundzewicz, Z.W.; Benestad, R.E.; Ceglarz, A. Perception of climate change and mitigation policy in Poland and Norway. In Climate Change and Its Impact on Selected Sectors in Poland; Kundzewicz, Z.W., Hov, Ø., Okruszko, T., Eds.; CHASE-PL: Poznan, Poland, 2017; pp. 216-244, ISBN 978-83-8104-735-7. 
91. Kundzewicz, Z.W.; Førland, E.J.; Piniewski, M. Challenges for developing national climate services-Can Poland learn from Norway? In Climate Change and Its Impact on Selected Sectors in Poland; Kundzewicz, Z.W., Hov, Ø., Okruszko, T., Eds.; CHASE-PL: Poznań, Poland, 2017; pp. 245-255. ISBN 978-83-8104-735-7.

92. Cai, H.; Lam, N.S.N.; Qiang, Y.; Zou, L.; Correll, R.M.; Mihunov, V. A synthesis of disaster resilience measurement methods and indices. Int. J. Disaster Risk Reduct. 2018, 31, 844-855. [CrossRef]

93. Oxfam. The Tsunami' s Impact on Women; Oxfam International: Boston, MA, USA, 2004; pp. 1-14, ISBN 978-1-84814-684-6.

94. Clauss-Ehlers, C.S.; Levi, L.L. Violence and community, terms in conflict: An ecological approach to resilience. J. Soc. Distress Homeless 2002, 11, 265-278. [CrossRef]

95. Ink, D. An analysis of the house select committee and white house reports on Hurricane Katrina. Public Adm. Rev. 2006, 66, 800-807. [CrossRef]

96. Hollnagel, E.; Fujita, Y. The Fukushima disaster-systemic failures as the lack of resilience. Nucl. Eng. Technol. 2013, 45, 13-20. [CrossRef] 